\title{
Getting Development Underway Through Faculty Involvement
}

\section{Dean Hustuft}

Moorhead State University

I had just accepted a new position, an assignment of starting a faculty/instructional development program. Now where does one begin? How can faculty support be generated? Certainly there are people on the campus who are willing to work at developing and promoting improved teaching and learning, but how can they be identified? This paper describes how the author, newly arrived at a university, was able to get faculty support for development by involving them directly in the process.

Stated succinctly, a faculty development committee was organized to work with me, the faculty/instructional developer. The creation of this committee was achieved in the following way: first, meetings were arranged with the academic deans and department chairs to become acquainted with them and talk about their views on faculty development. At the University, faculty growth and development is regarded as an important criterion in the promotion and tenure process. Therefore development is a concern, either directly or indirectly, to most people on campus. The concerns they spoke about were very real and concrete. The next step was to create and distribute a survey instrument that was used to get inpuit from faculty members. The results from this survey were rank-ordered to identify those problems and interests that were most common throughout the University. Viewpoints from department chairs 
and the deans, together with the results from the faculty survey, comprised the points that were used to request the formation of a faculty development committee. A meeting was arranged with the president of our local faculty association to review the information. This step was an important one to take because it is the faculty association's representatives who recommend new committees and people to serve on them. Members of the executive committee of the faculty association were supportive of the request, and the committee was created, with the approval of the administration.

Once a year our faculty members are asked to indicate which committees they are interested in serving on. This information is passed on to the president of the University, who makes the committee assignments. This was the procedure we used to constitute the faculty development committee and to obtain its charge.

The committee serves as an advisory group to the faculty/ instructional development officer. It consists of nine faculty members and the Dean of Instructional Resources. Proposals and recommendations may come from any member of the faculty or from within the committee. However it is the faculty/instructional development officer who provides the direction and leadership for the campus community.

\section{COMMITTEE INPUT}

Visibility for the faculty/instructional development program was chosen as the first priority of the committee. There was strong support among committee members to sponsor a day of faculty recognition, a day which would be proclaimed as a celebration of excellence in the classroom. This concept became the centerpiece for the committee's deliberations. Discussions were upbeat from the very start. Soon the focus was expanded to include students in the day's activities. The level of interest shown by committee members affected planning in a positive way. Their exuberance was shared among colleagues, and a feeling of anticipation began to build.

Committee members felt it would be valuable for the faculty to meet away from the campus, where there would be no telephone calls or other routine interruptions. A distance from campus would let participants have an opportunity to 
develop and exchange ideas without any need to break away from the group because a problem had come up. Faculty members would be randomly assigned to small discussion groups. This way insights and successful classroom experiences could be shared with people from different disciplines and departments. Small groups limited to 20 persons each were proposed to facilitate intra-group communication. Three topics were chosen from the faculty interest survey as areas for discussion: education and cultural values, student growth and development, and creativity in the classroom. Committee members felt these topics, which were of interest to a majority of those who responded to the survey, were also sufficiently general in nature to allow persons with different academic emphases to share their perspectives with others in the group.

A separate convenor was chosen for each topic. Convenors were selected from within the randomized groups and were people who indicated their willingness to preside over the discussion of one particular topic. Thus each convenor conducted only one group session. Recorders were also chosen for each small group and were asked to keep a record of the discussions and the issues which were raised.

Members of the faculty development committee were asked to recommend a keynote speaker for the day. We felt this person should be from another campus and have a solid reputation in his or her field. The speaker should also be able to work comfortably with small groups of people. The committee wanted the keynoter to mingle with people after setting the theme for their opening round of discussions. Each person suggested by committee members was given consideration. Finally an invitation was extended to Dr. Mihaly Csikszentmihalyi, who chairs the Committee on Human Development and who also chairs the Department of Behavioral Sciences at the University of Chicago, His talk was entitled "Enjoyment and the Transmission of Culture," a theme which complimented the topics chosen for the small group discussions.

It was decided to call this event "Learning Awareness Day." The name was chosen for its descriptive nature. We wanted to accomplish three goals on this day: to reaffirm the quality of teaching that takes place on the campus; to focus our attention upon concerns about teaching and learning we hold in common; and to establish the faculty/instructional 
development office as a place where people might come whenever they are interested in achieving even greater success in their teaching. This would be a day during which the faculty would collectively appraise their teaching efforts.

A brief training session was scheduled for those who agreed to serve as convenors. Parameters and guidelines for each of the three sessions were provided to the convenors along with a reprint of a recent article by the keynote speaker. A mailing was used as a followup to the session. Convenors were asked to keep the committee's guidelines in mind as they focused their group's deliberations. The faculty development committee felt that too much structure might be counterproductive. We wanted the exchanges to develop as spontaneously as possible.

The committee's proposal for a day celebrating excellence in the classroom was presented to the administration for review and approval. Following some minor changes in the approach and structure, the administration chose to release classes for the day, subject to each faculty member's discretion. Some classes, such as those which feature laboratory sessions or large lectures meeting only once or twice a week, were accommodated. Instructors who felt their classes would be irretrievably set back were similarly accommodated. Other faculty were urged to attend the day-long session.

Major plans were complete. A faculty retreat would be convened at a local conference center, while our students would attend a series of sessions dealing with life-long learning issues held on the campus. Documents were made available to report student attendance and indicate the particular sessions that were attended. These forms could be presented to a student's instructors at the next scheduled class meeting.

The administration provided the resources necessary to insure the day's success. Department chairs and academic deans were canvassed to obtain faculty rosters, including adjunct and part-time faculty. These names were put into a computer file which was used to generate the randomly designated discussion group assignments. The same file system was used to print out name tags for each person, denoting the specific discussion group to which he or she had been assigned and listing each person's department. 


\section{Publicizing the Event}

Members of the faculty development committee believed the day must be well publicized to underscore our goal of making Learning Awareness Day an event of major importance to the university community. We wanted to make the point that this day would be more than "just another workshop."

The student newspaper agreed to run an article announcing the day and followed this with a series of interviews featuring faculty and administrators. Some of the interviews conveyed feelings of anticipation. Others were skeptical that something like this would work. An editorial endorsing the event was included as a part of the series.

A press release was sent to the local daily newspaper highlighting the goals and format for the day. This release included background information about the keynote speaker. Arrangements were made to have local television news reporters include stories on Learning Awareness Day during their broadcasts and a press conference was scheduled on the day of the event. The press conference featured the keynote speaker interacting with faculty members during a question and answer session.

Local media representatives were willing to cooperate in providing this publicity because the idea of releasing classes for one day was unique in our area. Also, people in the University's service region are interested in education at all levels. Stories that involve local educational institutions are well received by readers and viewers.

A letter was sent to each faculty member from the faculty development committee explaining in detail the events planned for Learning Awareness Day. The tone of the letter was one of excitement and anticipation. A second mailing was sent to the faculty a week before the event, in the form of a brochure which gave details of the schedule. A second printing of the brochure was made available at the registration table of the retreat site.

\section{LEARNING AWARENESS DAY}

Learning Awareness Day began with a brief welcome from the President of the University. Several interested faculty and administrators from neighboring institutions had accepted our invitation to join the activities. The President was able to 
acknowledge their presence as well. The author, as faculty/ instructional development officer, greeted those who were in attendance, reviewed the committee's goals for the day, and presented the keynote speaker. Dr. Csikszentmihalyi's talk paralleled an article he had recently published and which had been given to the convenors during the training session.

The first small group discussion was an extension of the keynote speech. Since convenors were familiar with the points of the speech beforehand, the transition into the first session went smoothly. Some of the discussion groups sought to amplify the keynoter's remarks. Other groups preferred to critique the comments based upon their own experiences and perceptions. Still other groups used the keynoter's points as a bridge to discuss related concerns. But people were talking-and they were sharing ideas. The model chosen for Learning Awareness Day was beginning to work as planned.

Session two shifted focus to the growth and development of our students. In reviewing reports from the recorders of these discussion groups, it was interesting to observe the parallels that emerged from one discussion to the next. Faculty from many of the discussion groups (and from a majority of the departments) cited common student characteristics, perceived problems, and similar kinds of steps that were being used to resolve the problems. The fact that these views and operations were derived independently, for the most part, reinforced the percept that quality teaching was taking place across the campus.

The afternoon session focused upon creativity in the classroom. Several observations can be made about this session. First, none of the discussants felt they were able to define creativity in a manageable way. That being the case, the discussions turned to innovative classroom procedures. A sharing of experiences and personal philosophies of education was manifested. Recorders indicated the pleasure faculty expressed over new ideas, ideas they were willing to put to use. Some of the techniques were carefully picked apart, providing additional insights and revealing shortcomings. This was peer exchange in its finest hour. A number of the discussion groups asked the faculty development committee to do even more with this particular topic in the future.

Learning Awareness Day was concluded with a half-hour 
session recapping the events. The Vice President for Academic Affairs for the University presided over this segment and was joined by the keynote speaker. Together they gave their views of what had taken place and its value to both the University and to individual faculty members.

\section{ADDITIONAL ACTIVITIES}

Follow-up activities were essential, since it was intended that this day of celebration of classroom excellence would also be a springboard event for future plans. Faculty were sent an evaluation form to assess Learning Awareness Day. The items on this form were open-ended because the committee members wanted input rather than just a group of check marks. We wanted to know how well we had done, of course, but we also wanted to know what we could do better or differently in the future. Information was compiled from the evaluation and from the recorders. A report was assembled and distributed to each academic department, each academic dean, and to members of the central administration.

Responses to Learning Awareness Day were supportive, with 83 percent of the respondents indicating their approval of the committee's work. Approximately this same number felt a similar event should be planned again. Useful suggestions were offered regarding alternative models, sites, and topics.

A second instrument, designed to provide input for committee activities, was included with the evaluation instrument. This was a simple checklist that could be used to indicate issues and interests that should be pursued by the faculty/instructional development officer and members of the committee. Among those topics receiving the most support from respondents were student evaluation of classroom teaching, classroom climate (as it affects minority and female students), the development of critical thinking skills among students, and learning styles.

Based upon the level of support obtained from the faculty, the author decided to begin plans for a follow-up session concerned with learning styles. A member of the psychology department who is respected for her work in this area agreed to participate. This session has been planned for later in the academic year.

A faculty resource file has been compiled also. This file 
contains the names of people with expertise in aspects of the teaching/learning process who are willing to share their knowledge with other faculty. The author serves as a liaison and brings together faculty with an expressed interest in a topic and those who are able to provide guidance. This concept is proving to be useful for a number of reasons. In the beginning, we were interested in identifying people who could preside over sessions that address the areas identified in the interest checklist. But we have found the file to be most useful for short term needs. Individuals who have perceived needs can be put into immediate contact with someone who can provide help. A one-to-one working relationship is established. The faculty resource file is proving to be an effective way to keep faculty/instructional development a visible part of the university. A person who teaches philosophy may join with someone from the English department and another person from mathematics to work on strategies for developing critical thinking skills among students.

Several faculty members indicated an interest in developing a central location where they might congregate to discuss classroom concerns and issues. Interest in this concept was high enough that a subcommittee of the faculty development committee has been organized to investigate such a center. Another subcommittee is working out a proposal for a program that will provide some kind of tangible recognition for outstanding teaching.

This writer has seen an increase in the number of invitations for classroom visits. Upon request, the teaching performance is video recorded. Later the tape is reviewed with the faculty member. Afterwards the faculty member may either retain the tape or it is erased. In no case is it retained in the faculty/ instructional development office without the faculty member's permission. In other situations a paper and pencil evaluation form is provided for use by students to assess classroom teaching. Results of these evaluations are reviewed with the faculty member upon request. A third technique being used is a selfanalysis instrument for the faculty member. Those responses may then be correlated with the student evaluations as an estimate of how well the course objectives are being realized.

New instructional development projects have been inaugurated as the result of exchanges made during Learning Awareness 
Day. One entire course in behavior modification is being produced on video tape. A series of video tapes are being produced on management techniques. The energy management department is producing a series of multi-media programs concerned with energy conservation issues. Also in the planning stages are instructional units in education, accounting, English, and history. The administration has asked the author to expand his area of responsibility by taking a more direct role in assisting faculty members to obtain instructional grants. And finally, two-thirds of the members of the faculty development committee asked to be reassigned to the same group for a second year.

\section{FINAL OBSERVATIONS}

In one year's time the faculty development committee, working with the author, was able to plan Learning Awareness Day and then use that event as a means for establishing the viability of the faculty/instructional development program. Follow-up activities to benefit interested faculty members have been arranged, and more are being developed. We now know many of the interests and concerns of both faculty and administrators. This day celebrating excellence in the classroom was a faculty project from its inception. The day was planned by the committee, and each member fulfilled tasks assigned by the developer to make it a success. Committee members have joined others from the faculty and administration in endorsing plans for a similar kind of day in the future.

A solid working relationship between the faculty and the developer has been created. Nearly two dozen classroom improvement projects, both small and large in scale, have been initiated because of the attitude towards development that was cultivated one day in January.

Input from the grass roots level is absolutely necessary to create the interest level and expectancies that profoundly affect faculty and instructional development programs. It is equally vital to pursue contacts once they have been made-as rapidly as possible. Follow-up visits with each academic dean and department head have taken place or are scheduled to take place. 
Perhaps the most important outcome from working with a faculty committee is the interest that evolves in faculty/instructional development. Faculty committees do require time to assemble themselves and to function. Agendas must be set and agreed to. Sometimes it is necessary to prod people to move ahead with their deliberations. And, of course, the developer must do his or her homework to sustain the energy level of the committee. But faculty committees will return dividends for the time and work invested by a faculty/instructional developer. Committee members share their interest in projects with colleagues, and this excitement reaches the administration. The end result is a network of support that draws other faculty members into the program. They may be people who are willing to share their particular talents with others. Or they could be good instructors who want to do things even better in their classrooms, It could be a group of people who would like to meet together from time to time and discuss specific educational issues. Whatever the reason or concern, a faculty committee can play an important part in faculty/instructional development. There is no reason why a developer should struggle along alone when there are so many benefits to be accrued from involving others with the program. 